\title{
Phosphoproteins and protein-kinase activity in isolated envelopes of pea (Pisum sativum L.) chloroplasts
}

\author{
J. Soll
}

Botanisches Institut der Universität München, Menzinger Straße 67, D-8000 München 19, Federa1 Republic of Germany

\begin{abstract}
A protein kinase was found in envelope membranes of purified pea (Pisum sativum L.) chloroplasts. Separation of the two envelope membranes showed that most of the enzyme activity was localized in the outer envelope. The kinase was activated by $\mathrm{Mg}^{2+}$ and inhibited by ADP and pyrophosphate. It showed no response to changes in $\mathrm{pH}$ in the physiological range $(\mathrm{pH} 7-8)$ or conventional protein substrates. Up to ten phosphorylated proteins could be detected in the envelopemembrane fraction. The molecular weights of these proteins, as determined by polyacrylamide-gel electrophoresis were: two proteins higher than $145 \mathrm{kDa}, 97,86,62,55,46,34$ and $14 \mathrm{kDa}$. The $86-\mathrm{kDa}$ band being the most pronounced. Experiments with separated inner and outer envelopes showed that most labeled proteins are also localized in the outer-envelope fraction. The results indicate a major function of the outer envelope in the communication between the chloroplast and the parent cell.
\end{abstract}

Key words: Chloroplast envelope - Pisum (chloroplast envelopes) - Protein kinase - Protein phosphorylation.

\section{Introduction}

Chloroplasts are surrounded by a pair of unit membranes, called the envelope, which can be separated into inner and outer envelope. The envelope membranes have important functions in the flow of substances in and out of the plastid, i.e. transport of triosephosphate in exchange for orthophosphate $(\mathrm{Pi})$ by the phosphate translocator (Flügge and Heldt 1976) located in the inner enve-

Abbreviations: cAMP $=$ adenosine $2^{\prime}: 3^{\prime}$-cyclic monophosphate, $\mathrm{Pi} / \mathrm{PPi}=$ ortho-/pyrophosphate lope membrane, and transport of proteins, initiated by binding of the protein precursor to specific receptors located at the outer membrane (Pfisterer et al. 1982). The envelope plays also a key role in the biosynthesis of galactolipids (Douce and Joyard 1979) and prenyllipids (Soll et al. 1980). A means by which enzymatic and transport processes or information cascades can be regulated is by protein-phosphorylation-dephosphorylation. The envelope membranes of spinach are known to contain phosphoproteins (Laing and Christeller 1984; Soll and Buchanan 1983) and a role of phosphorylation-dephosphorylation in the ATP-dependent protein transport into the organelle has been discussed (Soll and Buchanan 1983).

Until now, no detailed data have been available for the function or number of phosphorylated proteins in the envelope membranes, although three ${ }^{32} \mathrm{P}$-labeled proteins have been described for spinach chloroplast envelopes (Laing and Christeller 1984; Soll and Buchanan 1983). We have, therefore, studied the distribution of phosphoproteins and protein-kinase activity in envelope membranes from purified pea chloroplasts.

\section{Material and methods}

Plant material. Pea plants (Pisum sativum, cv. Rosa Krone; Bayrische Futtersaatbau, München, FRG) were grown on vermiculite in the greenhouse for $10-14 \mathrm{~d}$. [y- $\left.{ }^{32} \mathrm{P}\right] \mathrm{ATP}(111 \mathrm{TBq}$. $\mathrm{mol}^{-1}$ ) was from Amersham-Buchler (Braunschweig, FRG). All other chemicals were purchased from commercial sources and were of the highest purity available.

Isolation of intact chloroplast and chloroplast components. Chloroplast were isolated in low ionic-strength medium as described by Nakatani and Barber (1977) and were further purified by centrifugation through a step silica sol gradient $(40 \% \mathrm{v}: \mathrm{v} / 80 \%$, $v: v$, Percoll) (Pharmacia Fine Chemicals, Uppsala, Sweden; Mourioux and Douce 1981). After this purification step, the chloroplast preparation is devoid of enzymatic activities such as NADH:cytochrome-c oxidoreductase, fumarase, catalase, 
glycolate oxidase or nitrate reductase (Mourioux and Douce 1981), indicating that it is essentially free of contamination by endoplasmatic reticulum, mitochondria, peroxisomes or cytoplasmic proteins. Envelope membranes were prepared from the purified intact chloroplasts (equivalent to $60 \mathrm{mg}$ of chlorophyll) by rupturing in hypotonic buffer solution followed by a floatation centrifugation in a three-phase discontinuous sucrose gradient $(3 \mathrm{~h} ; 100000 \mathrm{~g})$. The lysed chloroplast suspension was brought to $1.3 \mathrm{M}$ sucrose by adding solid sucrose to the solution. The slurry was overlayed with a $3-\mathrm{ml}$ cushion of 1.25 sucrose, followed by $1.2 \mathrm{M}$ and $0.3 \mathrm{M}$ sucrose $(10 \mathrm{ml}$ each; Cline et al. 1981).

Separation of inner and outer envelope membranes. Purified chloroplasts (equivalent to $60 \mathrm{mg}$ chlorophyll) were suspended in hypertonic sucrose solution for $10 \mathrm{~min}$ at $4^{\circ} \mathrm{C}$. The shrunken chloroplasts were ruptured either by a freeze-thaw cycle and inner and outer membranes separated by two consecutive sucrose gradients, essentially as described by Cline et al. (1981), or they were broken by a passage through a Yeda-Press and envelope membranes were separated by differential and densitygradient centrifugation, as in Block et al. (1983). Envelope membranes thus prepared were devoid of chlorophyll, as a marker for thylakoid membranes.

Assay of protein-kinase activity. Protein-kinase activity was measured by following the incorporation of ${ }^{32} \mathrm{P}$ from $[\mathrm{y}-$ ${ }^{32}$ P]ATP into the trichloroacetic-acid- and ethanol-insoluble fraction as in Soll and Buchanan (1983). Standard incubation mixtures (final vol $0.5 \mathrm{ml}$ ) contained $50 \mathrm{mM} \mathrm{N}$-Tris (hydroxymethyl)methylglycine-KOH, pH 7.6; $4 \mathrm{mM} \mathrm{MgCl}_{2} ; 300 \mu \mathrm{M}$ ATP containing $0.5-1 \cdot 10^{5} \mathrm{~Bq}\left[\mathrm{y}^{32} \mathrm{P}\right] \mathrm{ATP}$ and the indicated amounts of envelope membranes. The mixture was incubated for $15 \mathrm{~min}$ at $22^{\circ} \mathrm{C}$, the reaction was stopped by addition of 3 vol 12\% (w/v) trichloroacetic acid (TCA) and the products purified by three washes with $5 \%(\mathrm{w} / \mathrm{v}) \mathrm{TCA}$ and one wash with $96 \%(\mathrm{v} / \mathrm{v})$ ethanol. Recovered radioactivity in the washed pellets was determined using a liquid scintillation counter (Beckmann LS 100 C, Rotizint 22, Zinsser, Frankfurt, FRG). Alternatively, when proteins were analyzed, the ethanol-washed pellet was subjected to polyacrylamide-gel electrophoresis as described below.

Electrophoretic analysis of ${ }^{32}$ P-labeled envelope membranes. Lithium-dodecyl-sulfate polyacrylamide-gel electrophoresis was used to analyze unlabeled and ${ }^{32} \mathbf{P}$-labeled polypeptides from chloroplast envelope membranes. Following the ethanol wash described above, envelope membranes were solubilized at room temperature in a solution containing $60 \mathrm{mM} \mathrm{Na}_{2} \mathrm{CO}_{3}, 70 \mathrm{mM}$ dithiothreitol, $12 \%$ sucrose, $4 \%$ lithium dodecyl sulfate. Electrophoresis was carried out at $4^{\circ} \mathrm{C}$ in gels containing a $7.5-15 \%$ linear polyacrylamide gradient essentially as described by Joyard et al. (1983). Dried slab gels were subjected to autoradiography at $-80^{\circ} \mathrm{C}$ using an intensifying screen (MR 600; Agfa-Gevaert). Protein was estimated by the method of Lowry et al. (1951) using bovine serum albumin as standard.

\section{Results}

Distribution of phosphorylated proteins in chloroplast envelopes. We have recently demonstrated the presence of a protein kinase in the outer envelope membrane of spinach chloroplasts. As shown below, envelope membranes isolated from pea chloroplasts also contain protein-kinase activity. In

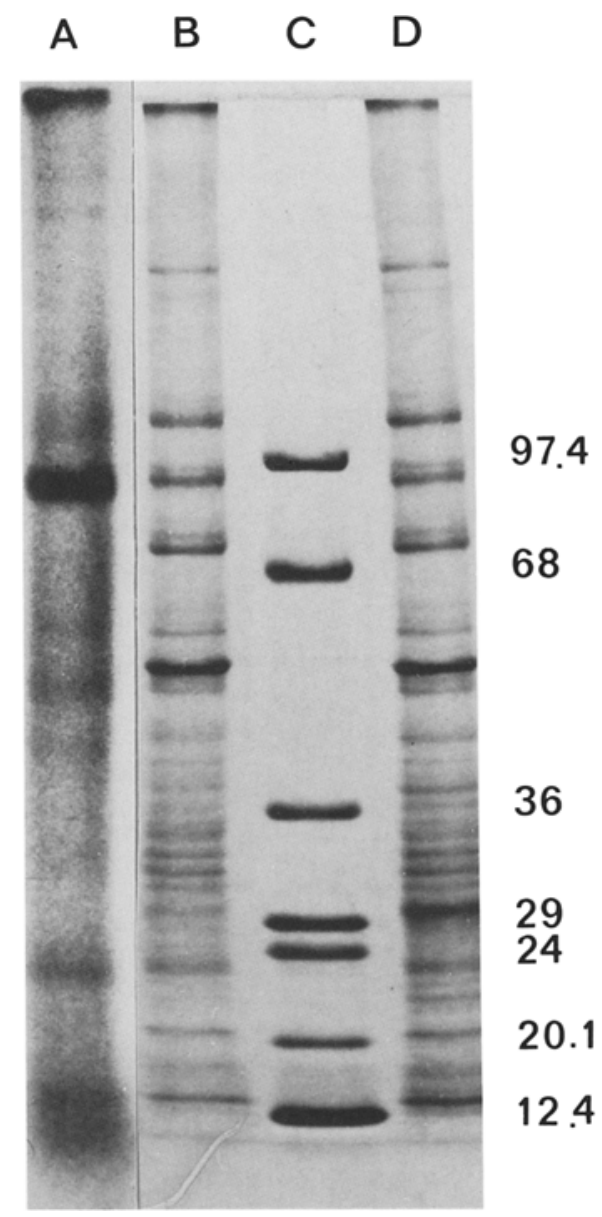

Fig. 1. Lithium-dodecyl-sulfate, 7-15\% polyacrylamide-gradient-gel electrophoresis of ${ }^{32} \mathrm{P}$-labeled and unlabeled envelope membranes from pea chloroplasts. Lane $A$, autoradiograph of lane $B$; lane $B, 52 \mu \mathrm{g}$ of ${ }^{32} \mathrm{P}$-labeled envelope protein were analyzed after $15 \mathrm{~min}$ incubation with $\left[\mathrm{y}_{-}{ }^{32} \mathrm{P}\right] \mathrm{ATP}$ and purification as described in Material and methods; lane $C$, molecular-weight standards in $\mathrm{kDa}$, phosphorylase b, 97.4; bovine serum albumin 68; egg albumin 45 (omitted in Fig. 1); glycerin-3-phosphate dehydrogenase 36 ; carbonic anhydrase 29 ; trypsinogen 24 ; soybean trypsin inhibitor 20.1 ; cytochrome c 12.4 ; lane $D, 60 \mu \mathrm{g}$ of unlabeled envelope protein

order to further characterize the ${ }^{32} \mathrm{P}$-labeled proteins of isolated envelope membranes, we studied their distribution by polyacrylamide-gel electrophoresis. As shown in Fig. 1, after 15 min incubation with $\left[\mathrm{y}^{32} \mathrm{P}\right] \mathrm{ATP}$, ten labeled bands can be determined on the autoradiograph. They span over a molecular-weight range from higher than $145 \mathrm{kDa}$ to around $14 \mathrm{kDa}$. Though some radioactivity remains at the origin of the gel, as a consequence of difficulties in the solubilisation of trichloroacetic-acid-precipitated proteins, a characteristic distribution of ${ }^{32} \mathrm{P}$-label confined to single protein bands is found. The most heavily labeled band is a protein around $86 \mathrm{kDa}$. Intermediate 

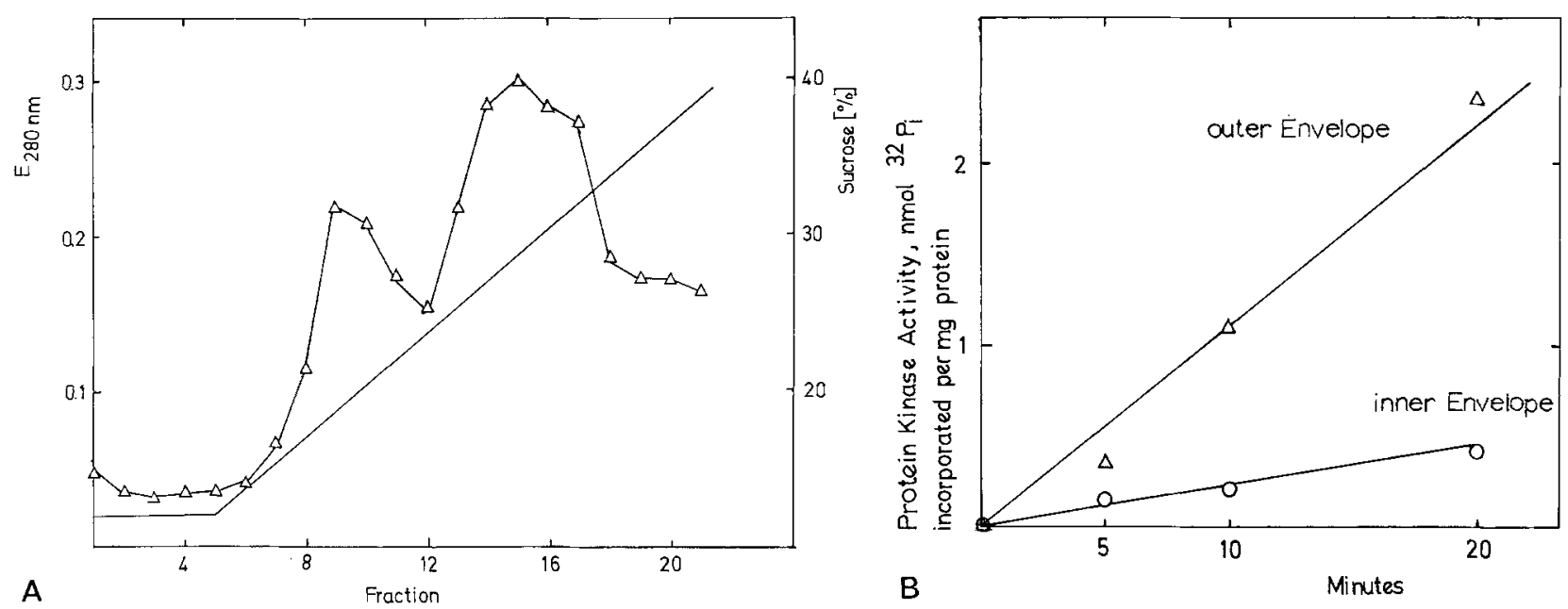

Fig. 2A, B. Localization of protein-kinase activity in chloroplast envelopes. Envelope membranes were fractionated into inner and outer membranes using the technique of Cline et al. (1981). A Shows a typical membrane-particle distribution on a linear sucrose gradient; B Time course of incorporation of $\left[\mathrm{y}^{32} \mathrm{P}\right] \mathrm{ATP}$ in inner- and outer-envelope membrane proteins from pea chloroplasts. Outer-membrane particles were recovered from fractions 7 through 10, inner ones from fractions 15 through 18 in A. Aliquots of the reaction mixture were removed at 0, 5, 10 and 20 min and treated as in Material and methods for analysis of radioactivity

stained bands are at approx. 55, 23 and $14 \mathrm{kDa}$. Another six bands are weakly labeled by ${ }^{32} \mathrm{P}$, i.e. two bands having a molecular weight higher than $145 \mathrm{kDa}$ and also bands at $97,62,46$ and $34 \mathrm{kDa}$. These ${ }^{32} \mathrm{P}$-labeled pea-envelope proteins are seen throughout all fresh preparations. In some cases additional labeled proteins can be detected at 75 and $13 \mathrm{kDa}$ (data not shown). At 0 min, no labeled protein bands are visible on autoradiographs, while the first protein to be labeled is the $86-\mathrm{kDa}$ protein. The number of labeled envelope proteins is much higher than those previously described for spinach envelopes from reports of Soll and $\mathrm{Bu}-$ chanan (1983) (two labeled bands at 14 and $24 \mathrm{kDa})$ and of Laing and Christeller (1984) (50.5, 29 and $13 \mathrm{kDa}$ ), though up to six bands were detected in very fresh preparations of envelope membranes obtained from purified spinach chloroplasts (data not shown).

In-vivo studies, using purified pea chloroplasts instead of envelope membranes under conditions identical to those described for envelope membranes in Material and methods, showed four phosphoproteins at 97, 86, 34, $14 \mathrm{kDa}$. The labeled spots at 86 and $14 \mathrm{kDa}$ being the most pronounced. Envelopes were purified as described by Cline et al. (1981).

The envelope fraction used in the above experiments consisted of a mixture of inner and outer envelope membranes. Recently devised techniques were applied to further localize the protein-kinase activity and to study the distribution of ${ }^{32} \mathrm{P}$-labeled proteins in inner and outer envelope membranes.
Two different methods for the separation are described in the literature (Block et al. 1983; Cline et al. 1981; see also Material and methods) both of which were compared in this study in respect of their protein pattern and distribution of labeled proteins. Similar data were obtained using the two separation methods; the freeze-thaw floating-up method described by Cline et al. (1981) (Figs. 2, 3 ) or the Yeda-Press method as developed by Block et al. (1983) (Fig. 4). Figure 2 a shows a typical separation of inner and outer membranes on a linear sucrose gradient as in Cline et al. (1984). Proteinkinase activity was mainly confined to the outer envelope (Fig. 2b). Electrophoretic analysis of inner- and outer-envelope proteins with subsequent autoradiography revealed that the labeled bands present in the mixture of envelope membranes (Fig. 1) are almost all detectable in the outer-membrane fraction (compare Figs. 1, 3, 4). Not only was the distribution of phosphorylated proteins and protein-kinase activity similar when the two different methods were applied, but the unlabeledprotein pattern was also very similar (Figs. 3, 4), except in some instances where differences in the high-molecular-weight region $(>100 \mathrm{kDa})$ could be detected.

During the purification of labeled proteins from free $\left[\mathrm{y}_{-}{ }^{32} \mathrm{P}\right]$ ATP by repeated trichloroaceticacid and ethanol washes, some proteins are partly lost, e.g. one of the marker proteins for the inner envelope, the phosphate translocator at $30 \mathrm{kDa}$. This phenomenon is also seen for other minor proteins (compare Figs. 3, 4). 


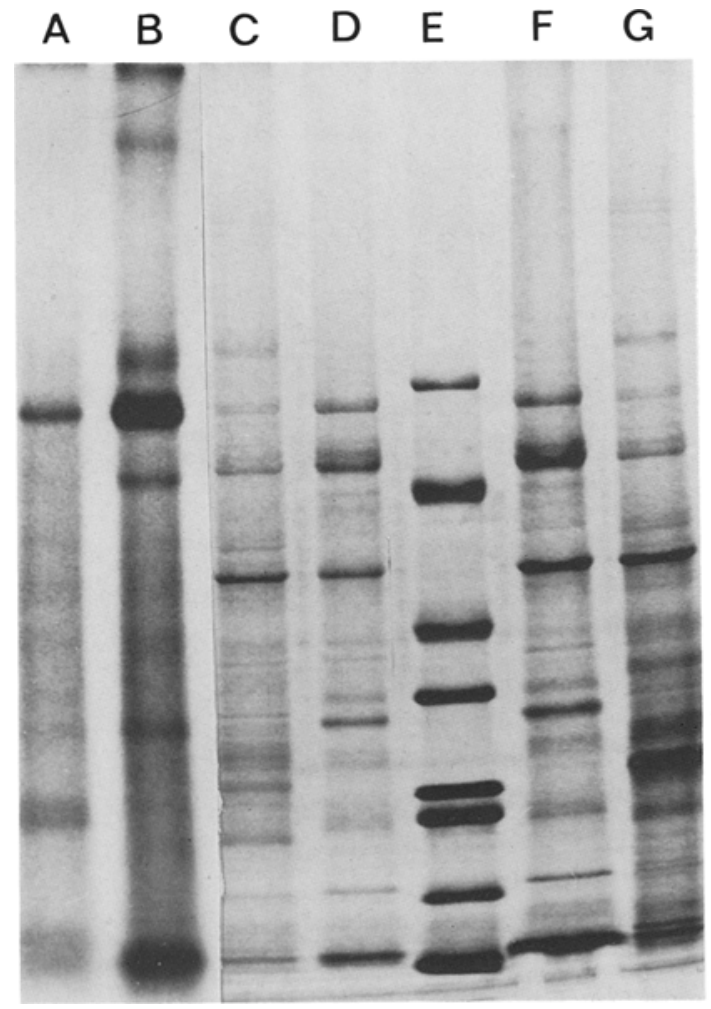

Fig. 3. Localization of proteins and phosphorylated proteins in the envelope. Inner and outer envelope membranes were separated by a freeze-thaw cycle, purified as described by Cline et al. (1981), and analyzed for their protein pattern and labeledprotein distribution by lithium-dodecyl-sulfate, $7-15 \%$ polyacrylamide-gradient-gel electrophoresis. Lanes $A, B$, autoradiographs of ${ }^{32} \mathrm{P}$-labeled inner- and outer-envelope membrane polypeptides, respectively; lane $C, 42 \mu \mathrm{g}$ of ${ }^{32} \mathrm{P}$-labeled polypeptides from the inner envelope membrane after trichloroacetic-acid and ethanol washes; lane $D, 45 \mu \mathrm{g}$ of ${ }^{32} \mathrm{P}$-labeled proteins from the outer membranes treated as in $\mathrm{C}$; lane $E$, molecular-weight standards as in Fig. 1; lane $F 90 \mu \mathrm{g}$ outerenvelope polypeptides; lane $G, 70 \mu \mathrm{g}$ inner-envelope polypeptides

For the outer envelope the most heavily labeled spot is again confined to a molecular weight at about $86 \mathrm{kDa}$; also strongly labeled is a band at $14 \mathrm{kDa}$. An intermediate spot is at $34 \mathrm{kDa}$. The proteins at higher than 145 , at 97, 75, 62, 55, 46, 23 are weakly labeled. About $15-20 \%$ of proteinkinase activity is present in the inner envelope fraction (compare Figs. 2, 3, 4). Labeled bands from the inner-membrane fraction have the same molecular weight as those from the outer except for two distinct bands at 26.5 and $18 \mathrm{kDa}$. So most of the kinase activity present in the inner-envelope fractions is probably due to cross-contamination, known to occur with the methods applied (Douce et al. 1984).

Characterization of envelope-bound protein-kinase activity. Attempts were made to further character-

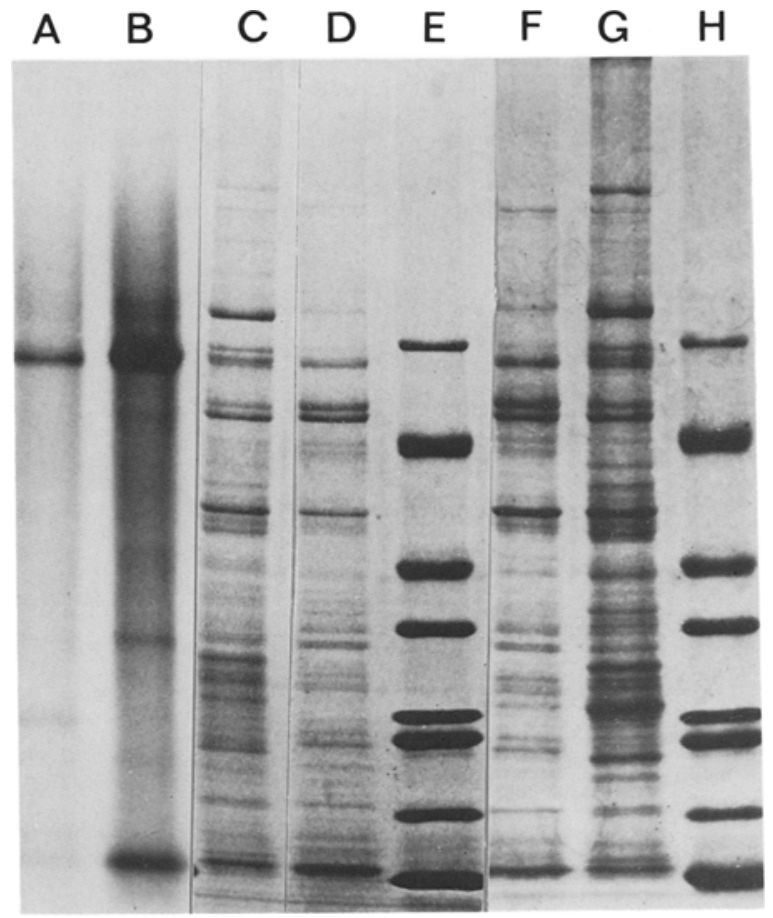

Fig. 4. Localization of proteins and phosphorylated proteins in the envelope. Pea chloroplast envelopes were separated in fractions enriched in inner and outer membranes by the method of Block et al. (1983) using a Yeda-press. Electrophoresis was as in Fig. 3. Lanes $A, B$ autoradiographs of lane $C$ and $D$ respectively; lane $C, 55 \mu \mathrm{g}$ of ${ }^{32} \mathrm{P}$-labeled polypeptides of the inner membrane after trichloracetic-acid and ethanol washes; lane $D, 53 \mu \mathrm{g}$ of ${ }^{32} \mathrm{P}$-labeled polypeptides of the outer membrane treated as $\mathrm{C}$; lane $E$, molecular-weight standards as in fig. 1 ; lane $F, 45 \mu \mathrm{g}$ of unlabeled outer-envelope protein; lane $G, 60 \mu \mathrm{g}$ of unlabeled inner-envelope protein; lane $H$, molecular-weight standards

ize the enzymic properties of the membrane-bound kinase. Envelope membranes heated to $98^{\circ} \mathrm{C}$ for $1 \mathrm{~min}$ showed no incorporation of ${ }^{32} \mathrm{P}$ into the trichloracetic-acid-insoluble fraction. Kinase activity was proportional to ATP concentration and under optimal conditions, showed a $V_{\max }$ of $0.69 \mathrm{nmol}$ of ${ }^{32} \mathrm{Pi}$ bound $\cdot \mathrm{min}^{-1} \cdot \mathrm{mg}^{-1}$ protein. The enzyme was inhibited by ADP in a competitive manner, with respective inhibitions of $65,80,90 \%$ observed when the ATP:ADP ratio was $1: 1.2,1: 3$ and $1: 8$. As determined by a Dixon plot, the $K_{i}$ for ADP was $45 \mu \mathrm{M}$ (Fig. 5). Various nucleoside diphosphates were tested and their inhibitory effect compared. Inhibition was assayed at $0.2 \mathrm{mM}$ ATP and $0.4 \mathrm{mM}$ effector concentration. Under these conditions a pronounced decrease of $57,53,62$ and $54 \%$ of the activity was found for ADP, guanosine $5^{\prime}$-diphosphate, uridine $5^{\prime}$-diphosphate, and cytidine $5^{\prime}$-diphosphate, respectively. The nucleoside monophosphates AMP, guanosine 5'-monophosphate, uridine 5 '-monophosphate and cytidine 


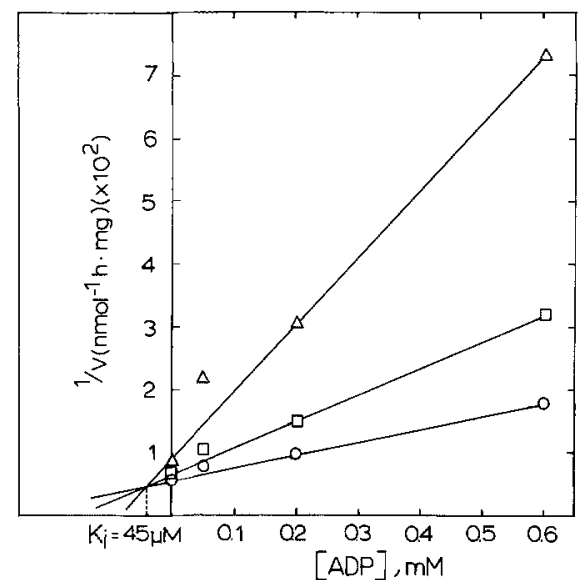

Fig. 5. Dixon-plot showing competitive inhibition of chloroplast-envelope-bound protein kinase by $\operatorname{ADP}(0,0.5 \mathrm{mM} ; \square$, $0.2 \mathrm{mM} ; \Delta, 0.075 \mathrm{mM}$ ATP)

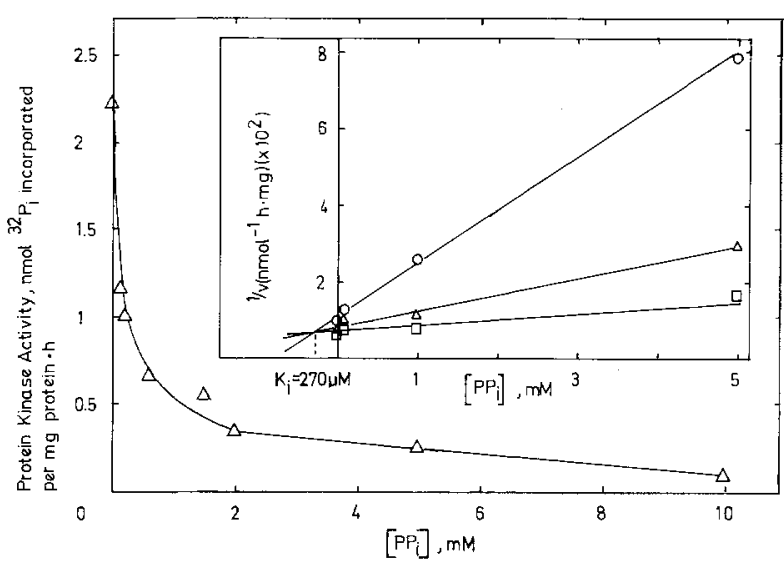

Fig. 6. Competitive inhibition of envelope-bound protein-kinase activity by sodium pyrophosphate. Inhibition was tested at $0.3 \mathrm{mM}$ ATP and the amounts of PPi indicated. The $\mathrm{K}_{\mathrm{i}}$ was determined by a Dixon plot (see insert) using different $\operatorname{ATP}(\square, 0.5 \mathrm{mM} ; \Delta, 0.3 \mathrm{mM} ; 0,0.1 \mathrm{mM}$ ) and effector concentrations

5'-monophosphate tested had no effect (ATP $0.2 \mathrm{mM}$, nucleoside monophosphates $0.2 \mathrm{mM}$ in the assay). Protein-kinase activity was also independent of adenosine $2^{\prime}: 3^{\prime}$-cyclic monophosphate (AMP) assayed under standard conditions using 30-100 $\mu \mathrm{M}$ cAMP. Thus, of the adenosine nucleosides looked at, only the adenosine-nucleoside diphosphates but not the monophosphates were found to alter, the activity of the protein kinase. Protein substrates like casein, histone or phosvitin $(250 \mu \mathrm{g})$ or the phosphatase inhibitor $\mathrm{NaF}$ $(20 \mathrm{mM})$ did not influence the enzymic activity. The envelope-bound protein kinase showed little alteration in response to changes of $\mathrm{pH}$ in the physiological range $6.8-8.4$ with a $10 \%$ increase of activity at 7.7. Heparin, a known inhibitor of cAMP-

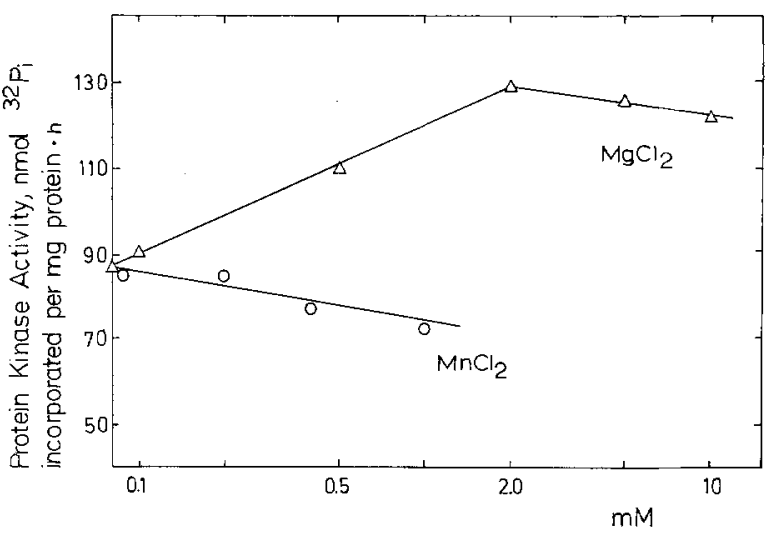

Fig. 7. Effect of $\mathrm{Mg}^{++}$and $\mathrm{Mn}^{++}$on envelope-membranebound kinase, isolated from purified pea chloroplasts

independent protein kinases in animal and plant tissues (Hathaway et al. 1980; Yan and Tao 1982) had no influence of ${ }^{32} \mathrm{P}$-incorporation in envelope polypeptides (used in different concentrations from $0.1-100 \mu \mathrm{g}$ in the standard assay). When the kinase activity was looked at in the presence of $\mathrm{Pi}$ $(0.1-20 \mathrm{mM})$, no changes from the control values were found. In contrast, with PPi included in the incubation mixture a marked inhibition of enzyme activity was detected (Fig. 6). The inhibition was already strong at low effector concentration, and, using a Dixon-plot, the $\mathrm{K}_{\mathrm{i}}$ was determined to be $270 \mu \mathrm{M}$ (see insert Fig. 6).

The only positive effector found so far is requirement for the divalent cation $\mathrm{Mg}^{2+}$ which could not be replaced by $\mathrm{Mn}^{2+}$ (Fig. 7). Calcium tested in concentrations up to $0.1 \mathrm{mM}$ was without effect.

\section{Discussion}

The data presented above show that protein phosphorylation is a widespread phenomenon within chloroplast membranes (Lin et al. 1982) and is not only restricted to the thylakoid network. The great number of labeled proteins, most of them confined to the outer envelope membrane is surprising. Until now only three phosphoproteins were known to occur in spinach envelopes. Evidence is now presented for more than ten phosphorylated proteins in pea envelopes. This finding is probably not without physiological significance. Though the number of labeled proteins found so far in spinach chloroplast envelopes is smaller, all of them are also described in this report for pea. Data for about six phosphoproteins from spinach envelope (data not shown) further support the idea, that polypeptide phosphorylation is a more widespread 
phenomenon than previously recognized. All major phosphoproteins are also detected in in-vivo studies using intact, purified pea chloroplasts. The number of labeled proteins in these experiments is smaller than that for isolated membranes (see above). This is probably a consequence of the low amount of envelope available from these experiments. The distribution of ${ }^{32} \mathrm{P}$-label is the same in both cases.

While many enzymatic activities are known to be localized in the chloroplast envelope (for a review, see Douce et al. 1984), these enzymes seem to be preferentially bound in the inner membrane, except for an acyl-CoA synthetase (Douce et al. 1984) and the protein-kinase activities for spinach (Soll and Buchanan 1983; Laing and Christeller 1984) and for pea (this paper). This is also represented by the distribution of proteins between the two membranes expressed by the lipid-to-protein ratio, which is about $2.5-3$ for the outer and $0.8-1$ for the inner membrane (Douce et al. 1984). A reason for the different distribution of phosphoproteins in the envelope is so far unknown. Little data is available on the origin of the two membranes and it has been speculated (Douce et al. 1984; Robinson 1980) that the outer membrane belongs to the so-called endomembrane system.

On the other hand, the chloroplast has many biosynthetic tasks to fulfill to support the parent cell; not only transport processes (sugars, amino acids, lipids, proteins) have to be regulated but also other messages (e.g. enzyme regulation, protein biosynthesis) have to cross the barrier of the chloroplast envelope membrane. One way by which enzymes can be regulated, or information transferred, is by the phosphorylation-dephosphorylation of the proteins in question. So the idea was put forward (Soll and Buchanan 1983) that the phosphorylation is neccessary for the ATP-dependent transport of proteins into the chloroplast. Experiments carried out in our laboratory so far have not yielded convincing evidence to either support or reject this hypothesis. It is still not known how phosphorylation alters the functions of the proteins in question and whether all phosphorylated envelope-bound proteins are functionally changed.

Two different methods were used to separate inner and outer envelopes, and both gave similar results regarding the polypeptide pattern of the respective membranes, the amount of protein-kinase activity and the distribution of phosphorylated proteins. In some cases, minor changes in the polypeptide pattern in the high-molecular-weight region $(>100 \mathrm{kDa})$ were observed; this might be caused by the fact that these proteins span the two membranes. While the method of Block et al. (1983) using a Yeda press is faster and gives higher yields, it is more difficult to use since it can easily produce contamination by thylakoid membranes if the experimental conditions are not very strictly controlled. The procedure of Cline et al. (1981) is more time consuming, tedious and has lower yields, but is easier to handle and not so prone to cross-contamination. Both fractionation techniques proved that the outer envelope membrane contains the protein-kinase activity as well as the target proteins. The question remains whether there is a one-protein-kinase, one-target-protein relation or whether the kinase enzyme is responsible for multiple polypeptide phosphorylation. Experiments to study the regulation of the kinase gave a uniform picture, e.g. competitive inhibition by ADP, PPi, substrate affinity, cAMP-independence, indicate a one-protein-kinase, multiple-target-protein relation.

Not much is known about the function or nature of the target proteins except their molecular weight as determined by polyacrylamide-gel electrophoresis. The only protein identified so far at the envelope membrane is the phosphate translocator, a $30-\mathrm{kDa}$ marker protein of the inner membrane (Flügge and Heldt 1976). Clearly much more work is needed to align enzyme activities and proteins with single polypeptides in the envelope membranes. This should add valuable information to our current knowledge of the importance of the envelope for the development and function of chloroplasts and the cooperation of the organelle with the entire cell.

I would like to thank Dr. Rüdiger for valuable discussions during the progress of this work and Mrs. Fischer for excellent technical assistance. This work was supported by the Deutsche Forschungsgemeinschaft.

\section{References}

Block, M.A., Dorne, A.J., Joyard, J., Douce, R. (1983) Preparation and characterization of membrane fractions enriched in outer and inner envelope membranes from spinach chloroplasts. J. Biol. Chem. 258, 13273-13280

Cline, K., Andrews, J., Mersey, B., Newcomb, E.H., Keegstra, K. (1981) Separation and characterization of inner and outer envelope membranes of pea chloroplasts. Proc. Natl. Acad. Sci. USA, 78, 3595-3599

Cline, K., Werner-Washburne, M., Andrews, J., Keegstra, K. (1984) Thermolysin is a suitable protease for probing the surface of intact pea chloroplasts. Plant Physiol. 75, 675-678

Douce, R., Block, M.A., Dorne, A.J., Joyard, I. (1984) The plastid envelope membranes, Subcell. Biochem., 10, 1-84

Douce, R., Joyard, J. (1979) Structure and function of the plastid envelope. Adv. Bot. Res. 7, 1-116 
Flügge, U.J., Heldt, H.W. (1976) Identification of a protein involved in phosphate transport of chloroplasts. FEBS Lett. 68, 259-262

Hathaway, G.M., Lubben, T.H., Traugh, J.A. (1980) Inhibition of casein kinase II by heparin. J. Biol. Chem. 255, 8038-8041

Joyard, J., Billecocq, A., Bartlett, S.G., Block, M.A., Chua, N.H., Douce, R. (1983) Localization of polypeptides to the cytosolic side of the outer envelope membrane of spinach chloroplasts. J. Biol. Chem. 258, 10000-10006

Laing, W.A., Christeller, J.T. (1984) Chloroplast phosphoproteins: distribution of phosphoproteins within spinach chloroplasts. Plant Sci. Lett. 36, 99-104

Lin, Z.F., Lucero, H.A., Racker, E. (1982) Protein kinase from spinach chloroplasts. J. Biol. Chem. 257, 12153-12156

Lowry, O.H., Rosebrough, H.J., Farr, A.L., Randall, R.J. (1951) Protein measurement with the Folin phenol reagent. J. Biol. Chem. 193, 265-275

Mourioux, G., Douce, R. (1981) Slow passive diffusion of orthophosphate between intact isolated chloroplasts and suspending medium. Plant Physiol. 67, 470-473

Nakatani, H.Y., Barber, J. (1977) An improved method for isolating chloroplasts retaining their outer membranes. Biochim. Biophys. Acta 461, 510-512

Pfisterer, J., Lachmann, P., Kloppstech, K. (1982) Transport of proteins into chloroplasts: Binding of nuclear-coded chloroplast protein to the chloroplast envelope. Eur. J. Biochem. 126, 143-148

Robinson, D.G. (1980) The role of endomembrane organelles in plant cell wall synthesis, In: Cell compartmentation and metabolic channeling, pp. 485-495, Nover, L., Lynen, F., Mothes, K., eds. VEB Gustav Fischer, Jena

Soll, J., Buchanan, B.B. (1983) Phosphorylation of chloroplast ribulose bisphosphate carboxylase-oxygenase small subunit by an envelope bound protein kinase in situ. J. Biol. Chem. 258, 6686-6689

Soll, J., Kemmerling, M., Schultz, G. (1980) Tocopherol and plastoquinone synthesis in spinach chloroplast subfractions. Arch. Biochem. Biophys. 204, 544-550

Yan, T.J., Tao, M. (1982) Purification and characterization of a wheat germ protein kinase. J. Biol. Chem. 257, $7037-7043$

Received 26 February; accepted 13 May 1985 